Discussion

\title{
Vitamin D: Daily vs. Monthly Use in Children and Elderly-What Is Going On?
}

\author{
Luca Dalle Carbonare ${ }^{1, *}$ (D), Maria Teresa Valenti ${ }^{1}$, Francesco del Forno ${ }^{1}$, Elena Caneva ${ }^{2}$ \\ and Angelo Pietrobelli ${ }^{2,3}$ \\ 1 Clinic of Internal Medicine, section D, Department of Medicine, University of Verona, Verona 37134, Italy; \\ mariateresa.valenti@univr.it (M.T.V.); francesco.delforno@gmail.com (F.d.F.) \\ 2 Pediatric Unit, Verona University Medical School, Verona 37122, Italy; elena.caneva1989@gmail.com (E.C.); \\ angelo.pietrobelli@univr.it (A.P.) \\ 3 Pennington Biomedical Research Center, Baton Rouge, LA 70808, USA \\ * Correspondence: luca.dallecarbonare@univr.it; Tel.: +39-45-812-6062; Fax: +39-45-802-7496
}

Received: 14 April 2017; Accepted: 20 June 2017; Published: 24 June 2017

\begin{abstract}
Vitamin D deficiency is highly prevalent among children and adults worldwide. Agreement exists that vitamin D deficiency should be corrected. However, the definitions of vitamin deficiency and effective vitamin D replacement therapy are inconsistent in the literature. Not only is the dosing regimen still under debate, but also the time and period of administration (i.e., daily vs. monthly dose). In pediatric as well as elderly subjects, dosing regimens with high vitamin D doses at less frequent intervals were proposed to help increase compliance to treatment: these became widespread in clinical practice, despite mounting evidence that such therapies are not only ineffective but potentially harmful, particularly in elderly subjects. Moreover, in the elderly, high doses of vitamin $\mathrm{D}$ seem to increase the risk of functional decline and are associated with a higher risk of falls and fractures. Achieving good adherence to recommended prophylactic regimens is definitely one of the obstacles currently being faced in view of the wide segment of the population liable to the treatment and the very long duration of prophylaxis. The daily intake for extended periods is in fact one of the frequent causes of therapeutic drop-outs, while monthly doses of vitamin D may effectively and safely improve patient compliance to the therapy. The aim of our paper is a quasi-literature review on dosing regimens among children and elderly. These two populations showed a particularly significant beneficial effect on bone metabolism, and there could be different outcomes with different dosing regimens.
\end{abstract}

Keywords: vitamin D; regimen; children; elderly

\section{Introduction}

The importance of vitamin D in bone metabolism is very well-known. Vitamin D deficiency is associated with increased risk for other non-musculoskeletal chronic diseases [1].

Vitamin D deficiency and insufficiency are highly prevalent among children worldwide [2]. In the adult population, the prevalence of vitamin D deficiency is also high and ranges from $79 \%$ to $98 \%$ in nursing home patients, increasing the risk of falls and fracture [3,4].

There is still an ongoing discussion to define the optimal 25OH vitamin D (25OHD) serum level for maintenance of bone health, and also what effective vitamin D replacement therapy should involve. In other words, it is not clear which dosing regimens should be used in different populations. However, the evolving consensus is now to recommend a 25OHD target level of $75 \mathrm{nmol} / \mathrm{L}$ in fragile elderly subjects who are at elevated risk of falls and fractures, and at least a level of $50 \mathrm{nmol} / \mathrm{L}$ for the adult population [3,4]. 
Thus far, there is no general agreement regarding the dose or the D2/D3 of vitamin D supplementation to reach the target level, even though there are several data showing the different impacts on increasing circulating 25OHD levels in patients on vitamin D supplements, of characteristics such as body mass index (BMI) (accounting up to $30 \%$ of variation in circulating 25OHD), type of supplement (vitamin D2 or D3), age, concomitant intake of calcium supplements and baseline 25OHD [5].

The main point is related to the fact that, in clinical practice, maintaining long-term adherence to daily dosages of vitamin $\mathrm{D}$ is often difficult, in both pediatric and elderly populations [6]. As a result, more convenient dosing regimens with high vitamin $\mathrm{D}$ doses at less frequent intervals were proposed and became widespread practice, despite mounting evidence that such therapies are not only ineffective but potentially harmful, particularly in adults [7].

While it has been shown an association between low $25 \mathrm{OH}$ vitamin D levels in childhood and increased occurrence of subclinical atherosclerosis in adulthood [2], definitive data are lacking on the effectiveness of vitamin D supplementation and dose requirements related to the improvement of lower extremity function in elderly. Interestingly, several studies suggested that higher monthly doses of vitamin D increase the risk of functional decline [8,9]. Until now, there are no consistent data suggesting the ideal regimen of supplementation, or comparing daily vs. monthly vitamin D administration.

In light of all the above questions, the aim of our paper is to evaluate dosing regimens among different populations, with particular attention to children and the elderly, to identify the best way to correct vitamin D deficiency, and to define the optimal $25 \mathrm{OH}$ vitamin serum level.

\section{Vitamin D in the Childhood}

\subsection{The First Year of Life}

In the first year of life, vitamin D status depends mainly on prophylaxis protocol. Breast milk contains insufficient amounts of vitamin $(<80 \mathrm{IU} / \mathrm{L})$ for vitamin D deficiency prevention [10]. Subjects under the age of six months should not be exposed to direct sunlight and in the winter period babies who are exclusively breastfed have lower blood levels of 25(OH)D. To prevent vitamin D deficiency, the American Academy of Pediatrics has recommended a supplement of $400 \mathrm{IU} /$ day from birth for children entirely or partially breastfed [11]. This supplementation is recommended until the child is weaned and drinks at least one liter/day of formula milk fortified with vitamin D. In Italy, Reference Levels of Nutrients and energy intake (LARN) recommend an intake of $400 \mathrm{IU} /$ day between six and twelve months of life [12]. The Italian Society of Paediatrics similarly recommends prophylaxis with $400 \mathrm{IU} /$ day of vitamin D for all infants from the first day of life up to one year of age, regardless of the type of feeding. This dosage is recommended for infants in the absence of risk factors for vitamin D deficiency [13]. Table 1 reports the international recommendations of vitamin $\mathrm{D}$ in subjects from birth to one year of age.

Table 1. Recommendations for vitamin D prophylaxis in the first year of life according to several international health Societies.

\begin{tabular}{|c|c|}
\hline Society & Vitamin D Supplementation \\
\hline $\begin{array}{l}\text { Society of Lawson Wilkins Pediatric } \\
\text { Endocrinology (Misra } 2008 \text { [14]) }\end{array}$ & $\begin{array}{l}\text { - } 400 \mathrm{IU} / \text { day should be initiated from the first day of life in all breastfed babies, and } \\
\text { children not breastfed do not take at least one liter/day of milk formula fortified with } \\
\text { vitamin D. } \\
\text { - Children with dark skin or who live at high latitudes }\left(>40^{\circ}\right) \text { may require vitamin D } \\
\text { supplementation at higher doses ( } 800 \mathrm{IU} / \text { day), especially during the winter months. }\end{array}$ \\
\hline ESPGHAN (Braegger 2013 [15]) & $400 \mathrm{IU} /$ day of vitamin D in all children during the first year of life. \\
\hline AAP (Wagner 2008 [11], Golden 2014 [16]) & $\begin{array}{l}\text { Children breastfed or partially breastfed with } 400 \mathrm{IU} / \text { day from the first day of life. } \\
\text { Supplementation until the child is weaned and takes at least } 1 \text { liter/day of vitamin } \\
\text { D-fortified milk formula. }\end{array}$ \\
\hline Endocrine Society (Holick 2011 [17]) & $\begin{array}{l}\text { Children in the first year of life at risk of vitamin D deficiency should receive } \\
\text { supplementation with } 400 \mathrm{IU} / \text { day to } 1000 \mathrm{IU} / \text { day. }\end{array}$ \\
\hline
\end{tabular}


Table 1. Cont.

\begin{tabular}{|c|c|}
\hline Society & Vitamin D Supplementation \\
\hline $\begin{array}{l}\text { Health Canada and the Canadian } \\
\text { Paediatric Society [18] }\end{array}$ & $\begin{array}{l}\text { 0-6 months } \\
\text { - } 400 \mathrm{IU} / \text { day in breastfed children. } \\
\text { - Children who are not breastfed require prophylaxis with vitamin D because infant } \\
\text { formula contains vitamin D. } \\
\text { - Children partially breastfed } 400 \mathrm{IU} / \text { day, regardless of how much formula milk taken. } \\
6-12 \text { months } \\
\text { - } 400 \mathrm{IU} / \text { day in children who are still exclusively breastfed or who take breast milk. }\end{array}$ \\
\hline United Kingdom Department of Health [19] & $\begin{array}{l}\text { - All children between } 6 \text { months and } 5 \text { years: to ensure a } 280 \mathrm{IU} / \text { day- }-340 \mathrm{IU} / \text { day } \\
\text { intake. Infants fed with formula milk do not require prophylaxis if they take at least } \\
500 \mathrm{~mL} / \text { day of formulation enriched milk with vitamin D. } \\
\text { - Breastfed babies may need to receive prophylaxis from the first month of life if the } \\
\text { mother did not take supplements during pregnancy. }\end{array}$ \\
\hline $\begin{array}{l}\text { Paediatric and Adolescent Bone Group UK } \\
\text { (Arundel } 2012 \text { [18]) }\end{array}$ & $\begin{array}{l}\text { It recommends that children fed exclusively by breastfeeding start prophylaxis } \\
\text { immediately after birth. }\end{array}$ \\
\hline $\begin{array}{l}\text { A French company of Paediatrics } \\
\text { (Vidailhet } 2012 \text { [19]) }\end{array}$ & $\begin{array}{l}\text { - Children fed exclusively by breastfeeding: } 1000 \mathrm{IU} / \text { day-1200 IU/day for the entire } \\
\text { lactation. } \\
\text { - Children under } 18 \text { months of age who take milk fortified with vitamin D3: } 600 \\
\text { IU/day-800 IU/day. } \\
\text { - Children under } 18 \text { months of age receiving unfortified cow's milk with vitamin D3: } \\
1000 \text { IU/day-1200 IU/day. }\end{array}$ \\
\hline $\begin{array}{l}\text { A Spanish company of Paediatrics } \\
\text { (Martinez Suarez } 2012 \text { [20]) }\end{array}$ & $\begin{array}{l}\text { For the child in the first year of life: } 400 \mathrm{IU} / \text { day or the use of formula milk sufficiently } \\
\text { enriched with vitamin D are the best strategies to ensure adequate vitamin intake. }\end{array}$ \\
\hline Central Europe (Płudowski 2013 [21]) & $\begin{array}{l}\text { - Prophylactic vitamin D should start from the earliest days of life, regardless of the } \\
\text { type of feeding. } \\
\text { - } 400 \mathrm{IU} / \text { day up to } 6 \text { months of life. } \\
\text { - } 400 \mathrm{IU} / \text { day- } 600 \mathrm{IU} / \text { day between } 6 \text { and } 12 \text { months of life, according to the } \\
\text { contribution of vitamin D daily with the diet. }\end{array}$ \\
\hline $\begin{array}{l}\text { Australia and New Zealand } \\
\text { (Paxton } 2013[22] \text { ) }\end{array}$ & Children at risk of vitamin D deficiency: $400 \mathrm{IU} /$ day at least for the first year of life. \\
\hline
\end{tabular}

Daily vs. Monthly Dose

Most clinical studies suggested daily regimens of vitamin D administration. However, daily intake of vitamin D must be supported by sufficient compliance from the family and subjects. Two recent studies instead evaluated the use of prophylaxis with vitamin D in intermittent doses $[23,24]$. In the first study, 120 children recruited during the vaccination campaign were divided into three groups: $200 \mathrm{IU} /$ day, $400 \mathrm{IU} /$ day, and 50,000 IU every two months. Subjects with 50,000 IU supplementation every two months showed an increase of $25(\mathrm{OH}) \mathrm{D}$ higher than the other two groups. At 6 months, $97 \%$ of the group of children treated with 50,000 IU every two months reached vitamin D levels $\geq 30 \mathrm{ng} / \mathrm{mL}$ (vitamin D sufficient). Only $37 \%$ of children in the first group and $77 \%$ of children in the second group reached the same level at follow-up. There were no reported cases of hypercalcemia or any other side effects during the study [23]. The second study evaluated 82 breastfed babies born to mothers with vitamin D deficiency. Children were divided into two groups. The first group (children with vitamin $\mathrm{D}<20 \mathrm{ng} / \mathrm{mL}$ ) received 30,000 IU of vitamin D in a single dose in the first week of life, followed by a second dose of 30,000 IU after a month if values of vitamin D were $<20 \mathrm{ng} / \mathrm{mL}$. If at control the values of $25(\mathrm{OH}) \mathrm{D}$ levels were $>20 \mathrm{ng} / \mathrm{mL}$, the prophylaxis continued with daily administration of $400 \mathrm{IU} /$ day. The second group was supplemented with $400 \mathrm{IU} /$ day from the second week of life. At follow-up performed after two months, $100 \%$ of children supplemented with $30,000 \mathrm{IU}$ in a single dose showed levels of $25(\mathrm{OH}) \mathrm{D}>20 \mathrm{ng} / \mathrm{mL}$, with $93.3 \%$ having levels $>30 \mathrm{ng} / \mathrm{mL}$. In the second group, $65 \%$ had at follow-up levels of $25(\mathrm{OH}) \mathrm{D}>20 \mathrm{ng} / \mathrm{mL}$ and $27.9 \%$ levels $>30 \mathrm{ng} / \mathrm{mL}$. The sufficient level of vitamin $\mathrm{D}(>30 \mathrm{ng} / \mathrm{mL})$ was achieved in all cases only in children treated with the first prophylactic scheme, while only $50 \%$ of children treated with $400 \mathrm{IU} /$ day reached this blood level of vitamin D. Both studied groups reported no side effects due to the administration of vitamin $\mathrm{D}$ [24]. Single dose or monthly administered vitamin $\mathrm{D}$ would offer greater adherence to prophylaxis by families and children and better efficacy in maintaining or increasing blood levels of vitamin D, in the absence of side effects or toxicity [13]. 


\subsection{Children Aged 1-18 Years}

Many international studies show that deficit and insufficiency of vitamin $\mathrm{D}$, defined as blood levels of $25(\mathrm{OH}) \mathrm{D}<20 \mathrm{ng} / \mathrm{mL}$ or between $20 \mathrm{ng} / \mathrm{mL}$ and $29 \mathrm{ng} / \mathrm{mL}$, are very common in industrialized countries and in developing countries. A multicenter study conducted in Europe on 1006 children between 12.5 years and 17.5 years found $42 \%$ of subjects with deficit and $39 \%$ with vitamin D insufficiency [25]. Data collected from Italian children are similar to those from Europeans and Americans, in particular the highest percentages of hypovitaminosis D are found in the neonatal period [26] and adolescence [27-29]. Status of vitamin D in infants is influenced by season of birth, ethnicity and maternal prophylaxis during pregnancy, while for adolescents and children important factors include the season in which they get the dosage, sun exposure, ethnicity, and BMI [13]. Important factors in children over one year of age are therefore sun exposure and the presence of certain risk factors for vitamin D deficiency such as non-Caucasian ethnicity, renal or liver failure, intestinal malabsorption, chronic treatment with anticonvulsants, corticosteroids, ketoconazole, antiviral and obesity. The level of recommended daily intake of vitamin D according to the American Academy of Pediatric and Italian LARN for Children between 1 and 18 years is $600 \mathrm{IU} /$ day [30]. The Endocrine Society recommends for children at risk of deficiency an intake of $600 \mathrm{IU} /$ day-1000 IU/day. It is also recommended that obese people receiving anticonvulsants, antiretrovirals, ketoconazole or corticosteroidsare recommended to receive an intake 2-3 times the daily requirements of vitamin D by age [17]. The Society for Adolescent Health and Medicine recommends supplementation with $600 \mathrm{IU} /$ day in adolescents with no risk factors and of at least $1000 \mathrm{IU} /$ day in adolescents at risk for vitamin D deficiency or insufficiency, in addition to vitamin D assumed with diet or produced during sun exposure [31]. These recommendations are important in order to ensure a correct acquisition of bone mass which is known to have its peak in adolescence, a process in which vitamin D is closely involved. Different international health organizations recommend doses of vitamin $\mathrm{D}$ on a daily basis, with one or two additional administrations during the winter, with doses of 80,000 to 200,000 IU. The French Society of Paediatrics suggests that children from 18 months to 5 years, with no risk factors for vitamin $\mathrm{D}$ deficiency should receive this dosage plus two supplementations of $80,000 \mathrm{IU}-100,000$ during the winter. The same approach is proposed for adolescents: two similar supplementary doses or a single dose of 200,000 IU during winter [19]. Mallet et al. recommend extending the recommendations for adolescents to children between 6 and 10 years old [32]. Table 2 reports the international recommendations of vitamin $\mathrm{D}$ in subjects from 1 year to 18 years of age.

Table 2. Indications for vitamin D prophylaxis between 1 year and 18 years of life according to several international health organizations.

\begin{tabular}{|c|c|}
\hline Society & Vitamin D Supplementation \\
\hline $\begin{array}{l}\text { The American Academy of Pediatrics } \\
\text { (Wagner } 2008 \text { [11], Golden } 2014 \text { [16]) }\end{array}$ & $\begin{array}{l}\text { Wagner 2008: } \\
\text { - Teenagers who do not get } 400 \mathrm{IU} / \text { day of vitamin D through milk or other } \\
\text { fortified foods: } 400 \mathrm{IU} / \text { day. } \\
\text { - Children with increased risk of vitamin D, malabsorption, anticonvulsants } \\
\text { treatment: } 400 \mathrm{IU} / \text { day. } \\
\text { Golden 2014: } \\
\text { Children over one year of age and adolescents: } 600 \mathrm{IU} / \text { day, obese subjects treated } \\
\text { with anticonvulsant drugs, corticosteroids, antifungal or antiretroviral drugs may } \\
\text { require 2-4 times the recommended dose of vitamin D. }\end{array}$ \\
\hline Endocrine Society (Holick 2011 [17]) & $\begin{array}{l}600 \text { to } 1000 \mathrm{IU} / \text { day. } \\
\text { Obese subjects treated with anticonvulsant drugs, corticosteroids, antifungals } \\
\text { such as ketoconazole and antiretroviral drugs should receive at least 2-3 times } \\
\text { the daily requirements of vitamin D for their age. }\end{array}$ \\
\hline ESPGHAN (Braegger 2013 [15]) & $\begin{array}{l}\text { - UL: } 2000 \mathrm{IU} / \text { day between } 1 \text { year and } 10 \text { years old, } 4000 \mathrm{IU} / \text { day between } \\
11 \text { years and } 17 \text { years. }\end{array}$ \\
\hline
\end{tabular}


Table 2. Cont.

\begin{tabular}{|c|c|}
\hline Society & Vitamin D Supplementation \\
\hline French company of Pediatrics (Vidailhet 2012 [19]) & $\begin{array}{l}\text { - In children } 18 \text { months }-5 \text { years: } 2 \text { doses of } 80,000 \mathrm{IU} \text { or } 100,000 \mathrm{IU} \text { in winter } \\
\text { (November to February) } \\
-6 \text { years to } 18 \text { years: } 2 \text { doses of } 80,000 \mathrm{IU} \text { or } 100,000 \mathrm{IU} \text { in the winter } \\
\text { (November to February) or a single dose of } 200,000 \mathrm{IU} \text {. }\end{array}$ \\
\hline $\begin{array}{l}\text { A Spanish company of Pediatrics } \\
\text { (Martinez Suarez } 2012[20] \text { ) }\end{array}$ & Daily intake: $600 \mathrm{IU} /$ day \\
\hline Central Europe (Płudowski 2013 [21]) & $\begin{array}{l}\text { - Supplementation with } 600 \mathrm{IU} / \text { day to } 1000 \mathrm{IU} / \text { day (depending on body weight) } \\
\text { of vitamin D and recommended between September and April. } \\
\text { - Supplementation with } 600 \mathrm{IU} / \text { day to } 1000 \mathrm{IU} / \text { day (depending on body weight) } \\
\text { of vitamin D and recommended throughout the year if good cutaneous } \\
\text { production of vitamin D is not guaranteed during the summer. } \\
\text { - In obese children and adolescents (BMI > 90th percentile for age and sex) } \\
\text { supplementation with } 1200 \mathrm{IU} / \text { day-2000 IU/day (depending on the severity of } \\
\text { obesity) of vitamin D between September and April is recommended. } \\
\text { - In obese children and adolescents (BMI > 90th percentile for age and sex) } \\
\text { supplementation with } 1200 \mathrm{IU} / \text { day-2000 IU/day (depending on the severity of } \\
\text { obesity) of vitamin D throughout the year is recommended. } \\
\text { - UL: } 2000 \mathrm{IU} / \text { day between } 1 \text { year and } 10 \text { years old, } 4000 \mathrm{IU} / \text { day between } \\
11 \text { years and } 18 \text { years. }\end{array}$ \\
\hline Australia and New Zealand (Paxton 2013 [22]) & $\begin{array}{l}\text { In subjects } 1 \text { year-18 years old with risk factors for vitamin D deficiency: } \\
400 \mathrm{U} / \text { day or } 150,000 \mathrm{IU} \text { early autumn. }\end{array}$ \\
\hline
\end{tabular}

Daily vs. Monthly Dose

Some studies that evaluate schedules of vitamin D administration other than daily supplementation offer encouraging results. Carnes et al. evaluated the efficacy and safety of high doses given at intervals every six months for a year. The children were divided into three groups treated with placebo, 150,000 IU every six months or 300,000 IU every six months. The study shows that the best scheme is administration of 300,000 IU/6 months, as this has the highest percentage of patients with normal vitamin D levels. During the study, there were no side effects and compliance remained high [33]. Kuchay et al. showed that intermittent treatment with vitamin D is safe and effective at achieving and maintaining adequate vitamin D levels. The administered dose was 60,000 IU/month for a year. After a year of monthly supplementation, average levels of 25(OH)D had risen from $12.0 \mathrm{ng} / \mathrm{mL}$ at the start to $32.6 \mathrm{ng} / \mathrm{mL}$ at the end of the study, subjects with insufficiency were reduced from $92.2 \%$ at time zero to $2.6 \%$ after 12 months, and none of the subjects developed cases of hypercalcemia [34]. In the study of Ghazi et al., 210 children were divided into three groups: one treated with 50,000 IU of vitamin D each month, the second with 50,000 IU every two months and the third with placebo. Treatment with 50,000 IU/month proved effective in increasing vitamin D levels but it does not seem to be enough to correct the deficit, in particular in young girls, who started the treatment with vitamin D levels significantly lower than their male counterparts. (19.25 $\pm 16.00 \mathrm{vs.}$ $14.00 \pm 40.50 \mathrm{nmol} / \mathrm{L})[35]$.

According to the Italian consensus on vitamin D in infants and children [13], vitamin D may be given with intermittent schedule (weekly or monthly for a total dose 18,000 to 30,000 IU/month) from the 5th or 6th year of life to adolescence in those subjects less compliant to daily treatment. Although vitamin D deficiency is detrimental to bone health, the consequent idea that higher doses are protective and confer a reduced risk of disease has been challenged by recent data in adults that indicate that doses of high vitamin $\mathrm{D}$ raise the incidence of falls and fractures [36,37]. These events were linked to the mode of administration (i.e., a single large bolus compared to smaller intermittent doses) [38]. Beyond skeletal health, similar curvilinear or U-shaped response has been described for other vitamin D outcomes, including all-cause mortality, cardiovascular disease and selected cancers. For these reasons the Institute of Medicine suggests caution against maintaining serum $25 \mathrm{OHD}$ concentrations above $50 \mathrm{ng} / \mathrm{mL}$ (125 nmol/L) [39], whereas levels up to $100 \mathrm{ng} / \mathrm{mL}$ 
( $250 \mathrm{nmol} / \mathrm{L})$ are cited as safe for both children and adults [17]. The specific vitamin D intake that results in excess or intoxication and the severity of the corresponding hypercalcemia have not been clearly established in pediatric age. Reports on vitamin D intoxication in infants and young children typically describe cases of receiving extremely large doses, in the range of 2.4 million to 4.5 million $\mathrm{IU}$, or approximately $40,000 \mathrm{IU} / \mathrm{kg}$ to $560,000 \mathrm{IU} / \mathrm{kg}$. This intake results in serum $25 \mathrm{OHD}$ levels in the range of $250 \mathrm{ng} / \mathrm{mL}-670 \mathrm{ng} / \mathrm{mL}$ leading to severe hypercalcemia [40,41]. Serum calcium concentrations in the range of $14-18 \mathrm{mg} / \mathrm{dL}$ (normal value: $>3.5 \mathrm{mmol} / \mathrm{L}-4.5 \mathrm{mmol} / \mathrm{L}$ ) were reported, with occasional values as high as $20 \mathrm{mg} / \mathrm{dL}$. Among these cases, there is significant variability in the amount of vitamin $\mathrm{D}$ administered and the resulting serum 25OHD concentrations. Furthermore, even with comparable serum $25 \mathrm{OHD}$ levels, the severity of hypercalcemia and symptomatology is unpredictable. Vogiatzi et al. suggest some recommendations for the prevention of vitamin D excess and intoxication in pediatrics [42]. They discourage empirical therapy of vitamin D deficiency with high vitamin D doses (such as single high-dose oral Vitamin D (stoss) therapy) without previous documentation of 25OHD concentrations and monitoring $25 \mathrm{OHD}$ and serum calcium levels. Health care providers should also consider monitoring vitamin D levels in infants and children receiving treatment doses at the upper ranges currently recommended. Although there is insufficient evidence to guide the frequency of such testing, Vogiatzi et al suggest 25(OH)D measurements no more than every six months [42]. According to these data, prophylaxis with vitamin $\mathrm{D}$ is critical to prevent hypovitaminosis $\mathrm{D}$ and the effects on bone metabolism and the whole body. Attention should always be paid to the cumulative dose administered and the risk of toxicity.

\section{Vitamin D in the Elderly}

\subsection{Elderly Population}

Patients over 70 years old represent a frail population in which vitamin D deficiency is frequent and often associated with comorbidities, therefore recommendations for prevention and supplementation of $25 \mathrm{OHD}$ are needed to maintain optimal vitamin D levels.

In of our study, we collected the main articles and guidelines published from 2011 to 2016 evaluating efficacy and safety of different vitamin D dosing regimens of supplementations in the elderly population. There is no common agreement worldwide to define a standard dose of cholecalciferol to prevent hypovitaminosis D. Current guidelines from the Institute of Medicine recommends a daily intake of 800 UI, whereas the Endocrine Society Clinical Practice Guideline endorses an intake of 1500 UI-2000 UI daily in people aged 70 years and older [7,43].

Osteoporosis Australia recommends an intake of at least $800 \mathrm{IU}$ in people over 70 years, and even higher doses in specific conditions, such as sun avoiders [44].

In the United Kingdom, instead, people aged 65 years and over as well people with limited sunlight exposure are advised to take daily vitamin D supplements of only 400 IU [45].

A "tailored" dose is likely to be more effective in maintaining vitamin D levels over the therapeutic threshold, because of the high individual variability.

In Italy, the recommendations from the Italian Society for Osteoporosis, Mineral Metabolism and Skeletal Diseases (SIOMMMS) to correct vitamin D deficiency are based on 25OHD baseline levels and require a loading dose to be administered within few weeks plus a maintaining daily supplement dose, similar to the dose regimen suggested by the UK National Osteoporosis Society Practical Guides [45,46].

We did not find relevant results regarding the compliance to the therapy (no studies evaluated the compliance as the primary endopoint), however poor adherence to daily dosing of medications and supplements is reported. In the study by Binkley et al., from 2011, which followed 64 adults over one year, the compliance to daily supplementation was slightly worse compared to monthly supplementation (91-95\% vs. 100\%) [1]. 
Another study, by Papaioannou et al., in 2011, showed the adherence to daily vitamin D supplementation of $83 \%$ (patients who consumed at least $80 \%$ of tablets) [47]. Compliance in real life is expected to be even lower than what is described in literature; a deferred administration of supplements is supposed to be useful to obtain a higher adherence to the therapy and better 25-OHD blood levels.

In the last few years, several trials comparing different daily or monthly dosing regimens of vitamin D currently adopted worldwide resulted in $20-25 \%$ of patients having suboptimal vitamin D status (at least $30 \mathrm{ng} / \mathrm{mL}$ ), even when 50,000 IU were administered monthly (1600 IU/day) [1,47,48]. In addition, the relevant impact on circulating vitamin D levels of variables such as BMI, age or type of supplements will probably lead to a personalized supplementation strategy tailored to the patient. Table 3 reports the international recommendations of vitamin D supplements in the adult population.

Table 3. Indications for vitamin D supplements in the adult population according to the international health organizations.

\begin{tabular}{|c|c|}
\hline Society & Vitamin D Supplementation \\
\hline Institute of Medicine (2010 [43]) & $\begin{array}{l}600 \mathrm{IU} / \text { day, } 18 \text { years- } 70 \text { years old } \\
800 \mathrm{IU} / \text { day, over } 70 \text { years old }\end{array}$ \\
\hline Endocrine Society Clinical Practice Guideline (2011 [49]) & $1500 \mathrm{IU} /$ day-2000 IU / day, over 19 years old \\
\hline Osteoporosis Australia (2016 [44]) & $\begin{array}{l}\text { At least } 600 \mathrm{IU} / \text { day, under } 70 \text { years old } \\
\text { At least } 800 \mathrm{IU} / \text { day, over } 70 \text { years old } \\
\text { Sun avoiders or people at risk of vitamin D deficiency: } \\
1000 \mathrm{IU} / \text { day-2000 IU / day }\end{array}$ \\
\hline National Osteoporosis Society Practical Guides (2013 [45]) & $\begin{array}{l}\text { People aged } 65 \text { years and over, people who are not exposed to } \\
\text { much sun, pregnant and breastfeeding women: } 400 \text { IU/day }\end{array}$ \\
\hline $\begin{array}{l}\text { Italian guidelines for diagnosis, prevention and treatment } \\
\text { of osteoporosis (2015 [46]) }\end{array}$ & $\begin{array}{l}\text { Baseline vit. D level < } 25 \mathrm{nmol} / \mathrm{L} \text { : cumulative dose 600,000 IU } \\
\text { supporting dose } 2000 \mathrm{IU} / \text { day } \\
\text { Baseline vit. D level } 25 \mathrm{nmol} / \mathrm{L}-50 \mathrm{nmol} / \mathrm{L} \text { : cumulative dose } \\
400,000 \mathrm{IU} \text { supporting dose } 1000 \mathrm{IU} / \text { day } \\
\text { Baseline vit. D level } 50 \mathrm{nmol} / \mathrm{L}-75 \mathrm{nmol} / \mathrm{L} \text { : cumulative dose } \\
\text { 100,000 IU supporting dose } 800 \mathrm{IU} / \text { day }\end{array}$ \\
\hline
\end{tabular}

Generally, these guidelines are based on 25OHD levels, and do not consider the impact of body weight on increasing circulating $25 \mathrm{OHD}$ levels, which accounts for more than $30 \%$ of individual variation [5].

\subsubsection{Vitamin D, Weight and BMI}

The influence of weight as well as BMI in conditioning the serum levels of vitamin D has already been evaluated.

Zittermann et al. analyzed the potential determinants of vitamin D levels and found that dose per $\mathrm{kg}$ body weight per day could explain $34.5 \%$ of variation in circulating 25OHD [5]. Additional significant predictors were type of supplement (vitamin D2 or vitamin D3), age, concomitant intake of calcium supplements and baseline 25OHD levels. Table 4 shows Vitamin D daily supplementation according to weight, age and target $25 \mathrm{OHD}$ level $75 \mathrm{nmol} / \mathrm{L}$, considering a baseline $25 \mathrm{OHD}$ level $25 \mathrm{nmol} / \mathrm{L}$.

Table 4. Body weight impact on determining optimal vitamin D daily dose [5].

\begin{tabular}{ccc}
\hline Body Weight (kg) & 30-Year-Old Person & 70-Year-Old Person \\
\hline 50 & $42 \mu \mathrm{g}(1680 \mathrm{IU})$ & $24 \mu \mathrm{g}(960 \mathrm{IU})$ \\
75 & $63 \mu \mathrm{g}(2520 \mathrm{IU})$ & $36.5 \mu \mathrm{g}(1460 \mathrm{IU})$ \\
100 & $84 \mu \mathrm{g}(3360 \mathrm{IU})$ & $49 \mu \mathrm{g}(1960 \mathrm{IU})$ \\
\hline
\end{tabular}

Calculated daily vitamin D3 dose for achieving a target $25 \mathrm{OHD}$ of $75 \mathrm{nmol} / \mathrm{L}$ in vitamin D deficient individuals, based on the paper by Zittermann et al. [5]. 
Wijnen et al. underlined that the most effective way to correct vitamin D deficiency in elderly subjects is to administer a personalized loading dose based on body weight and baseline 25OHD levels within few weeks to normalize 25OHD status, then to continue with a supporting dose given monthly (or even every two weeks, in view of the half-life of 25OHD of two weeks) based on body weight $[4,5]$. This approach seems to be efficient and at the same time safe and able to achieve a satisfying adherence to the treatment of the elderly [4,5]. Due to its clinical practical relevance, as already indicated by the algorithm used in the study from Wijnen et al., it is desirable to include the role of BMI in vitamin D supplementation in further guidelines as well as vitamin D baseline levels [5].

\subsubsection{Daily vs. Monthly Dose}

To improve adherence of patients to treatment, a deferred regimen is proposed by many authors as a valid alternative to daily treatment. However, there is growing evidence that infrequent high-dose vitamin D supplements might be less effective or even harmful. Pekkarinen et al., in 2009, have shown that supplementing vitamin $\mathrm{D}$ every four months is less efficient compared to the equivalent dose in daily administration [50]; moreover, a double-blind, placebo-controlled trial of more than 2000 women aged 70 years or older showed a significant association between annual oral administration of high-dose cholecalciferol and an increased risk of falls and fractures [36].

The effect of a loading dose in addition to daily vitamin $\mathrm{D}$ regimen in increasing vitamin $\mathrm{D}$ levels was evaluated by Papaioannou et al., and the study showed no significant differences in 25OHD values over three months of treatment, between the groups supplemented with or without a loading dose [47]. This result might have been influenced by the difference of supplements used for loading dose (vitamin D2) and daily administration (vitamin D3).

Meekiins et al., among 39 non-lactating women aged 18 years-40 years old, compared the different pharmacokinetics of a 150,000 IU single dose vs. a 5.000 IU daily dose of cholecalciferol over 28 days, and showed no difference in the cholecalciferol area under the curve between the two groups, although the single dose group had a significantly greater mean of 25OHD [51].

Another study was set to evaluate the effect of daily and monthly dosing of D2 or D3 on circulating 25OHD; the frequency of dosing did not significantly impact 25OHD levels, but the compliance to the treatment was higher in the monthly group. Additionally, the results showed that vitamin D3 is significantly more effective than D2 in increasing serum 25OHD over 12 months [1].

The above-mentioned interesting study from Wijnen et al. in subjects with a mean age of 84 years, compared the efficacy of an individualized cholecalciferol loading dose vs. a daily dose regimen of cholecalciferol $800 \mathrm{IU}$; the loading dose was calculated according to the algorithm $(40 \times(25 \mathrm{OHD}$ target level $-25 \mathrm{OHD}$ baseline level) $\times$ body weight), and administered in doses of 50,000 IU twice a week until the total dose was reached [4]. The results showed that patients supplemented with a personalized loading dose reached optimal vitamin D levels within five weeks, with a very large difference in percentage of patients compared to the daily dose group. The administration of a loading dose based on body weight and baseline 25OHD values seems to normalize vitamin D levels in a faster and much more efficient way [4]. It also suggested that the supplementation doses recommended by some of the current guidelines (i.e., Australia Osteoporosis, Institute of Medicine, Endocrine Society Clinical Practice Guidelines) are possibly not effective in correcting vitamin D deficiency in the elderly population.

On the other hand, Bischoff-Ferrari et al. pointed out the controversial role of vitamin D supplementation in the prevention of falls and fractures; the study involved 200 women, selected on the basis of a prior fall, with a mean age of 78 years over one year, divided into three groups based on different monthly vitamin D3 treatments: 24,000 IU/monthly (control group), 60,000 IU/monthly or $24,000 \mathrm{IU} / \mathrm{monthly}$ plus $300 \mathrm{mcg}$ calcifediol. Although higher doses of supplements were more effective in reaching reach levels of $30 \mathrm{ng} / \mathrm{mL}$, there were no benefits to lower extremity function; moreover, in the two high-dose groups the risk of falls was significantly increased [8]. This study showed a 5.5 times greater risk of falling in patients reaching the highest quartile of $25 \mathrm{OHD}$ level $(44.7 \mathrm{ng} / \mathrm{mL}-98.9 \mathrm{ng} / \mathrm{mL})$ compared with those reaching the lowest quartile $(21.3 \mathrm{ng} / \mathrm{mL}-30.3 \mathrm{ng} / \mathrm{mL})$, suggesting a U-shaped 
curve (rather than a J-shaped curve) correlation of the effect of vitamin D status on prevention of falls [8]. Further, Smith et al. supported the evidence of a U-shaped curve response to vitamin D3 dose and fall rate and a potential difference between high and medium doses of vitamin D [52].

These results might support the conservative (although not completely effective) approach of IOM recommendations of $800 \mathrm{IU} /$ day of vitamin D3, and cautions against higher doses of vitamin D3, even though they are required to obtain an optimal 25OHD target level [7].

While it is clear that $25 \mathrm{OHD}$ levels should be maintained up to a target level of $30 \mathrm{ng} / \mathrm{mL}$, further studies are required to identify a possible upper threshold for the safety of 25OHD levels.

The detrimental effects on efficacy and safeness of high and/or deferred doses of vitamin D supplementation showed by the latest trials are not completely clear and are currently under investigation. The negative outcome on bone health is probably also related to the fact that high doses of vitamin $\mathrm{D}$ increase FGF-23 concentration, sclerostin and Dickkopf-1 (DKK-1). The sclerostin and DKK-1 increase inhibits Wnt signaling, and might trigger an upregulation of 1,25-dihydroxyvitamin D3 24-hydroxylase, resulting in increased metabolism and blood levels of 1,25-dihydroxyvitamin D3 [7,49,53].

In the studies we analyzed, no significant differences in hypercalcemia (rarely detected) or urinary calcium levels were found between daily or deferred vitamin D supplements administration $[1,47,50,51]$ (Table 5).

Table 5. Synthetize findings from recent trials on vitamin D dosing regimen.

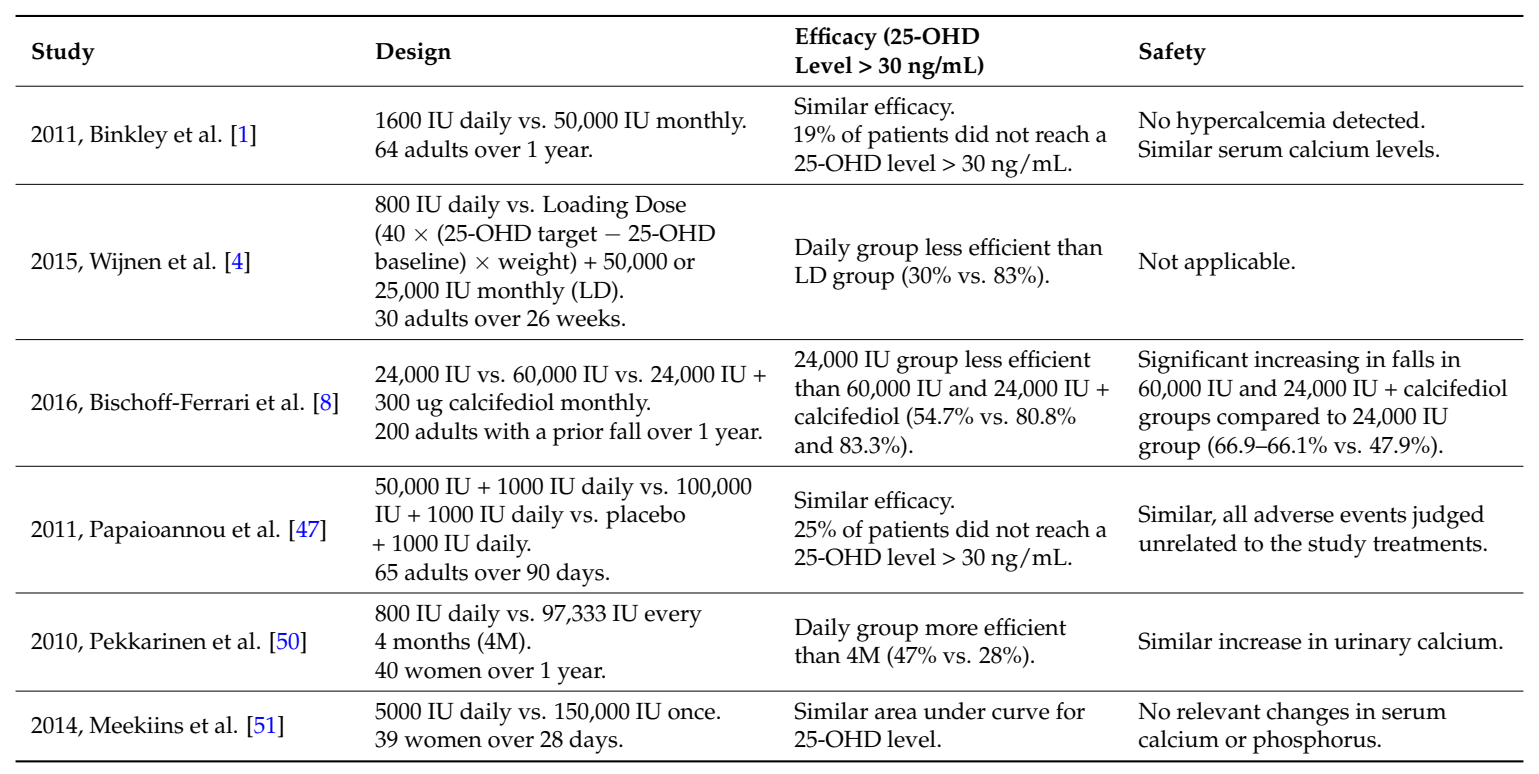

\section{Discussion}

Timing and dosing regimen are crucial for vitamin D supplementation. Daily administration is supposed to be the most physiological way to correct vitamin D deficiency, but a less frequent administration is likely to improve patient compliance to the treatment, and help obtain a greater mean vitamin D 25-hydroxylation [1,51].

In Italy in the first year of life, an intake of $400 \mathrm{IU} /$ day from six to twelve months is recommended [12], even though, as reported in Table 1, different international health organizations give specific and sometimes slightly different recommendations due to different sun exposures and study results. In children and adolescents from 1 to 18 years of age, the recommended daily intake of Vitamin D is 600 IU/day, according to the American Academy of Pediatrics [30]. However, once again, looking at Table 2, different international health organizations give different suggestions for the 1-18 age range. These recommendations come from studies where potentially conflicting factors were considered and results were clearly different. 
Among the elderly too, as reported in Table 3, different international health organizations give different recommendations for Vitamin D supplementation, introducing more confusion. To improve adherence of patients to treatment, a deferred regimen is proposed by many authors as a valid alternative to daily treatment, even though infrequent high-dose vitamin D supplement might be less effective or even harmful. In Italy, in elderly subjects, the current recommendations suggest normalizing 25OHD levels within few weeks with a loading dose based on baseline 25OHD concentration, which is a simplification of the effective dose able to normalize vitamin D levels. Interestingly, some authors suggest the use of a specific algorithm to calculate the loading dose, combining vitamin $\mathrm{D}$ levels and weight $[4,54]$. This approach is interesting because it represents an effort to define a more tailored treatment. From another point of view, the loading dose approach has been criticized by other authors as a cause of increased risk of falls and fractures [7]. Moreover, this negative result emerging from the study by Bischoff-Ferrari might be influenced by the selection criteria (patients with a prior fall) and by the lack of a placebo group. From another point of view, this conflicting result should be explained with the effect exerted by high doses of cholecalciferol that induce an acute increase of FGF-23, and consequently of turnover [53]. Based on these observations, the best approach seems to be a loading dose calculated using the abovementioned algorithm, followed by a daily/monthly maintaining dose, chosen on the basis of the characteristics of the patient.

\section{Conclusions}

In summary, the best approach to correct a vitamin D deficiency is still debated and could be specific for different age groups. To give clear and practical guidelines, it could be time to set up an expert panel to identify the best dosage of vitamin D at different ages. Many other variables could be included in the analysis to obtain the desirable dosage.

However, after a critical revision and analysis of all evidence, we could suggest, as key factors, considering bone mass analysis in children and the role of weight or BMI in the elderly in order to define "the Vitamin D picture". It is also fundamental to ensure a correct acquisition of bone mass which is known to reach its peak in adolescence, a process in which vitamin D is closely involved.

Finally, we can suggest the administration of a loading dose based on body weight and baseline $25 \mathrm{OHD}$ values to normalize vitamin D levels, while it is urgent to define the optimal regimen of vitamin D supplementation for maintaining normal levels, having a clear picture of daily vs. monthly administration, and low vs. high dosage.

Acknowledgments: The authors thank Riccardo Giannandrea for the English language revision.

Author Contributions: Luca Dalle Carbonare and Angelo Pietrobelli conceived the theme, wrote the manuscript, and shared responsibility for the final content. Elena Caneva, Francesco del Forno acquired data. Maria Teresa Valenti: analyzed and interpreted data. Francesco del Forno, Elena Caneva and Maria Teresa Valenti drafted the manuscript.

Conflicts of Interest: The authors declare no conflict of interest.

\section{References}

1. Binkley, N.; Gemar, D.; Drezner, M.K. Evaluation of ergocalciferol or cholecalciferol dosing, 1600 IU daily or 50,000 IU monthly in older adults. J. Clin. Endocrinol. Metab. 2011, 96, 981-988. [CrossRef] [PubMed]

2. Juonala, M.; Voipio, A.; Pahkala, K.; Viikari, J.S.A.; Mikkila, V.; Kahonen, M. Childhood 25-OH vitamin D levels and carotid intima-media thickness in adulthood: The cardiovascular risk in young finns study. J. Clin. Endocrinol. Metab. 2015, 100, 1469-1476. [CrossRef] [PubMed]

3. Agarwal, N.; Mithal, A.; Shukla, M. Effect of two different doses of oral cholecalciferol supplementation on serum 25-hydroxy-vitamin D levels in healthy Indian postmenopausal women: A randomized controlled trial. Indian J. Endocrinol. Metab. 2013, 17, 883-889. [CrossRef] [PubMed]

4. Wijnen, H.; Salemink, D.; de Boer, H. Vitamin D supplementation in nursing home patients: Randomized controlled trial of standard daily dose versus individualized loading dose regimen. Drugs Aging 2015, 32, 371-378. [CrossRef] [PubMed] 
5. Zittermann, A.; Ernst, J.B.; Borgermann, J. Vitamin D supplementation, body weight and human serum 25-hydroxyvitamin D response: A systematic review. Eur. J. Nutr. 2014, 53, 367-374. [CrossRef] [PubMed]

6. Tang, B.M.; Eslick, G.D.; Nowson, C.; Smith, C.; Bensoussan, A. Use of calcium or calcium in combination with vitamin D supplementation to prevent fractures and bone loss in people aged 50 years and older: A meta-analysis. Lancet 2007, 370, 657-666. [CrossRef]

7. Sanders, K.M.; Stuart, A.L.; Williamson, E.J.; Simpson, J.A.; Kotowicz, M.A.; Young, D.; Nicholson, G.C. Annual high-dose oral vitamin D and falls and fractures in older women: A randomized controlled trial. JAMA 2010, 303, 1815-1822. [CrossRef] [PubMed]

8. Bischoff-Ferrari, H.A.; Dawson-Hughes, B.; Orav, E.J.; Staehelin, H.B.; Meyer, O.W.; Theiler, R.; Dick, W.; Willet, W.C.; Egli, A. Monthly high dose vitamin D treatment for the prevention of functional decline. JAMA Intern. Med. 2016, 176, 175-183. [CrossRef] [PubMed]

9. Dawson-Hughes, B.; Harris, S.S. High-dose vitamin D supplementation: Too much of a good thing? JAMA 2010, 303, 1861-1862. [CrossRef] [PubMed]

10. Saggese, G.; Bertelloni, S.; Baroncelli, G.I. Determination of vitamin D and 25-hydroxyvitamin D in human milk. Rev. Ped. Prev. Soc. 1989, 39, 81-87.

11. Wagner, C.L.; Greer, F.R. American Academy of Pediatrics Section on Breastfeeding; American Academy of Pediatrics Committee on Nutrition. Prevention of rickets and vitamin D deficiency in infants, children, and adolescents. Pediatrics 2008, 122, 1142-1152. [CrossRef] [PubMed]

12. Italian Society of Human Nutrition (SINU). Reference Levels of Nutrients and Energy Intake for Italian Population, 2012 revision. In Proceedings of the XXXV SINU National Congress, Bologna, Italy, 22-23 October 2012.

13. Di Mauro, G.; Saggese, G. Italian Consensus on vitamin D in Infants and Children. Prev. Soc. Pediatr. 2015, 3 , 154-188.

14. Misra, M.; Pacaud, D.; Petryk, A. Vitamin D deficiency in children and its management: Review of current knowledge and recommendations. Pediatrics 2008, 122, 398-417. [CrossRef] [PubMed]

15. Braegger, C.; Campoy, C.; Colomb, V. Vitamin D in the healthy European pediatric population. J. Pediatr. Gastroenterol. Nutr. 2013, 56, 692-701. [CrossRef] [PubMed]

16. Golden, N.H.; Abrams, S.A. Committee on Nutrition Optimizing bone health in children and adolescents. Pediatrics 2014, 134, e1229-e1243. [CrossRef] [PubMed]

17. Holick, M.F.; Binkley, N.C.; Bischoff-Ferrari, H.A. Evaluation, treatment, and prevention of vitamin D deficiency: An Endocrine Society clinical practice guideline. J. Clin. Endocrinol. Metab. 2011, 96, 1911-1930. [CrossRef] [PubMed]

18. Vitamin D Supplementation for Northern Native Communities. Indian and Inuit Health Committee, Canadian Paediatric Society. CMAJ 1988, 138, 229-230.

19. Arundel, P.; Ahmed, S.F.; Allgrove, J. British Paediatric and Adolescent Bone Group's position statement on vitamin D deficiency. BMJ 2012, 345, e8182. [CrossRef] [PubMed]

20. Vidailhet, M.; Mallet, E.; Bocquet, A. Vitamin D: Still a topical matter in children and adolescents. A position paper by the Committee on Nutrition of the French Society of Paediatrics. Arch. Pediatr. 2012, 19, 316-328. [CrossRef] [PubMed]

21. Martinez Suarez, V.; Moreno Villares, J.M.; Serra Dalmau, J. Comite de Nutricion de la Asociacion Espanola de Pediatrics. Recommended intake of calcium and vitamin D: Positioning of the Nutrition Committee of the AEP. An. Pediatr. 2012, 77, e1-e8.

22. Płudowski, P.; Karczmarewicz, A.; Bayer, M. Practical guidelines for the supplementation of vitamin D and the treatment of deficits in Central Europe-recommended vitamin D intakes in the general population and groups at risk of vitamin D deficiency. Endokrynol. Pol. 2013, 64, 319-327. [CrossRef] [PubMed]

23. Paxton, G.A.; Teale, G.R.; Nowson, C.A.; Mason, R.S.; McGrath, J.J.; Thompson, M.J.; Siafarikas, A.; Rodda, C.P.; Munns, C.F. Australian and New Zealand Bone and Mineral Society; Osteoporosis Australia. Vitamin D and health in pregnancy, infants, children and adolescents in Australia and New Zealand: A position statement. Med. J. Aust. 2013, 198, 142-143. [CrossRef] [PubMed]

24. Shakiba, M.; Sadr, S.; Nefei, Z. Combination of bolus dose vitamin D with routine vaccination in infants: A randomized trial. Singap. Med. J. 2010, 51, 440-445.

25. Shakiba, M.; Pahloosye, A.; Mirouliaei, M. Comparison of two regimens of vitamin D supplementation for vitamin D-deficient neonates. Singap. Med. J. 2014, 55, 266-270. [CrossRef] 
26. Gonzalez-Gross, M.; Valtueña, J.; Breidenassel, C. Vitamin D status among adolescents in Europe: The Healthy Lifestyle in Europe by Nutrition in Adolescence Study. Br. J. Nutr. 2012, 107, 755-764. [CrossRef] [PubMed]

27. Cadario, F.; Savastio, S.; Magnani, C. High prevalence of vitamin D deficiency in native versus migrant mothers and newborns in the North of Italy: A call to act with a stronger prevention program. PLoS ONE 2015, 10, e0129586. [CrossRef] [PubMed]

28. Vierucci, F.; del Pistoia, M.; Fanos, M. Prevalence of hypovitaminosis D and predictors of vitamin D status in healthy Italian adolescents. Ital. J. Pediatr. 2014, 40, 54. [CrossRef] [PubMed]

29. Franchi, B.; Square, M.; Sandri, M. 25-hydroxyvitamin D serum level in children of different ethnicity living in Italy. Eur. J. Pediatr. 2015, 174, 749-757. [CrossRef] [PubMed]

30. Stagi, S.; Pelosi, P.; Strano, M.; Poggi, G.; Manoni, C.; de Martino, M.; Seminara, S. Determinants of Vitamin D levels in italian children and adolescents: A longitudinal evaluation of cholecalciferol supplementation versus the improvement of factors influencing $25(\mathrm{OH})$ D status. Int. J. Endocrinol. 2014, 2014, 583039. [CrossRef] [PubMed]

31. American Academy of Pediatrics. Dietary Reference Intakes for Calcium and Vitamin D. Pediatrics 2012, 130, e1424.

32. Society for Adolescent Health and Medicine. Recommended vitamin D intake and management of low vitamin D status in adolescents: A position statement of the society for adolescent health and medicine. J. Adolesc. Health 2013, 52, 801-803. [CrossRef]

33. Mallet, E.; Gaudelus, J.; Reinert, P.; Stagnara, J.; Bénichou, J.; Basuyau, J.P.; Maurin, M.; Cordero, J.; Roden, A.; Uhlrich, J. Vitamin D status in 6- to 10-year-old children: A French multicenter study in 326 children. Arch. Pediatr. 2014, 21, 1106-1114. [CrossRef] [PubMed]

34. Carnes, J.; Quinn, S.; Nelson, M. Intermittent high-dose vitamin D corrects vitamin D deficiency in adolescents: A pilot study. Eur. J. Clin. Nutr. 2012, 66, 530-532. [CrossRef] [PubMed]

35. Kuchay, M.S.; Jevalikar, G.S.; Mithal, A.; Mishra, S.K.; Dang, N. Efficacy and safety of a single monthly dose of cholecalciferol in healthy school children. J. Pediatr. Endocrinol. Metab. 2016, 29, 413-416. [CrossRef] [PubMed]

36. Ghazi, A.A.; Hosseinpanah, F.M.; Ardakani, E.; Ghazi, S.; Hedayati, M.; Azizi, F. Effects of different doses of oral cholecalciferol on serum $25(\mathrm{OH}) \mathrm{D}, \mathrm{PTH}$, calcium and bone markers during fall and winter in schoolchildren. Eur. J. Clin. Nutr. 2010, 64, 1415-1422. [CrossRef] [PubMed]

37. Smith, H.; Anderson, F.; Raphael, H.; Maslin, P.; Crozier, S.; Cooper, C. Effect of annual intramuscular vitamin D on fracture risk in elderly men and women-A population-based, randomized, double-blind, placebo-controlled trial. Rheumatology 2007, 46, 1852-1857. [CrossRef] [PubMed]

38. Sanders, K.M.; Nicholson, G.C.; Ebeling, P.R. Is high dose vitamin D harmful? Calcif. Tissue Int. 2013, 92, 191-206. [CrossRef] [PubMed]

39. Ross, A.C.; Manson, J.E.; Abrams, S.A. The 2011 report on dietary reference intakes for calcium and vitamin D from the Institute of Medicine: What clinicians need to know. J. Clin. Endocrinol. Metab. 2011, 96, 53-58. [CrossRef] [PubMed]

40. Atabek, M.E.; Pirgon, O.; Sert, A. Oral alendronate therapy for severe vitamin D intoxication of the infant with nephrocalcinosis. J. Pediatr. Endocrinol. Metab. 2006, 19, 169-172. [CrossRef] [PubMed]

41. Joshi, R. Hypercalcemia two to hypervitaminosis D: Report of seven patients. J. Trop. Pediatr. 2009, 55, 396-398. [CrossRef] [PubMed]

42. Vogiatzi, M.G.; Jacobson-Dickman, E.; de Boer, D. Vitamin D supplementation and Risk of Toxicity in Pediatrics: A Review of current literature for the Drugs, and Therapeutics Committee of the Pediatric Endocrine Society. J. Clin. Endocrinol. Metab. 2014, 99, 1132-1141. [CrossRef] [PubMed]

43. Ross, A.C.; Taylor, C.L.; Yaktine, A.L.; del Valle, H.B. Dietary Reference Intakes for Calcium and Vitamin D; Committee to Review Dietary Reference Intakes for Vitamin D and Calcium; Institute of Medicine; National Academies Press: Washington, DC, USA, 2010.

44. Osteoporosis Australia Medical and Scientific Advisory Committee; Osteoporosis Australia: Sydney, Australia, 2016.

45. Francis, R.; Aspray, T.; Fraser, W.; Gittoes, N.; Javaid, K.; Macdonald, H.; Pate, S.; Selby, P.; Tanna, N.; Bowring, C. Vitamin D and Bone Health: A Practical Clinical Guideline for Patient Management; National Osteoporosis Society: Camerton, UK, 2013. 
46. Rossini, M.; Adami, S.; Bertoldo, F.; Diacinti, D.; Gatti, D.; Giannini, S.; Giusti, A.; Malavolta, N.; Minisola, S.; Osella, G.; et al. Guidelines for the diagnosis, prevention and management of osteoporosis. Reumatismo 2016, 68, 1-39. [CrossRef] [PubMed]

47. Papaioannou, A.; Kennedy, C.C.; Adachi, J.D. A randomized controlled trial of vitamin D dosing strategies after acute hip fracture: No advantage of loading doses over daily supplementation. BMC Musculoskelet. Disord. 2011, 12, 135. [CrossRef] [PubMed]

48. Khawaja, N.; Liswi, M.; Ajlouni, K. Vitamin D dosing strategies among Jordanians with hypovitaminosis D: A randomized controlled trial. J. Pharm. Pract. 2017, 30, 172-179. [CrossRef] [PubMed]

49. Turner, C.; Dalton, N.; Inaoui, R.; Fogelman, I.; Fraser, W.D.; Hampson, G. Effect of a 300,000 IU loading dose of ergocalciferol (vitamin D2) on circulating 1,25(OH)2-vitamin D and fibroblast growth factor-23 (FGF-23) in vitamin D insufficiency. J. Clin. Endocrinol. Metab. 2013, 98, 550-556. [CrossRef] [PubMed]

50. Pekkarinen, T.; Valimaki, V.-V.; Valimaki, M.J. The same annual dose of 292000 IU of vitamin $D_{3}$ (cholecalciferol) on either daily or four monthly basis for elderly women: 1-year comparative study of the effects on serum $25(\mathrm{OH}) \mathrm{D}_{3}$ concentrations and renal function. Clin. Endocrinol. 2010, 72, 455-461. [CrossRef] [PubMed]

51. Meekiins, M.E.; Oberhelman, S.S.; Thacher, T.D. Pharmacokinetics of daily versus monthly vitamin D3 supplementation in non-lactating women. Eur. J. Clin. Nutr. 2014, 68, 632-634. [CrossRef] [PubMed]

52. Smith, L.M.; Gallagher, J.C.; Suiter, C. Medium doses of daily vitamin D decrease falls and higher doses of daily vitamin D3 increase falls: A randomized clinical trial. J. Steroid Biochem. Mol. Biol. 2017. [CrossRef] [PubMed]

53. Sankaralingam, A.; Roplekar, R.; Turner, C.; Dalton, R.N.; Hampson, G. Changes in dickkopf-1 (DKK1) and sclerostin following a loading dose of vitamin D2 (300,000 IU). J. Osteoporos. 2014, 2014, 682763. [CrossRef] [PubMed]

54. Van Groningen, L.; Opdenoordt, S.; van Sorge, A.; Telting, D.; Giesen, A.; de Boer, H. Cholecalciferol loading dose guideline for vitamin D-deficient adults. Eur. J. Endocrinol. 2010, 62, 805-811. [CrossRef] [PubMed]

(C) 2017 by the authors. Licensee MDPI, Basel, Switzerland. This article is an open access article distributed under the terms and conditions of the Creative Commons Attribution (CC BY) license (http:/ / creativecommons.org/licenses/by/4.0/). 